\title{
Effects of sill processes on the distribution of epineustonic competent larvae in a stratified system of Southern Chile
}

\author{
Carlos Molinet $^{1,6,7, *}$, Arnoldo Valle-Levinson ${ }^{2}$, Carlos A. Moreno ${ }^{3,7}$, \\ Mario Cáceres ${ }^{4}$, Mónica Bello ${ }^{5}$, Manuel Castillo ${ }^{5}$ \\ ${ }^{1}$ Instituto de Acuicultura, Universidad Austral de Chile, Los Pinos s/n, Puerto Montt, Chile \\ ${ }^{2}$ Department of Civil and Coastal Engineering, University of Florida, 365 Weil Hall, PO Box 116580, Gainesville, \\ Florida 32611, USA \\ ${ }^{3}$ Instituto de Ecología y Evolución, Universidad Austral de Chile, Casilla 567, Valdivia, Chile \\ ${ }^{4}$ Universidad de Valparaiso, Facultad de Ciencias del Mar y Recursos Naturales, Av. Borgoño 16344, Viña del Mar, Chile \\ ${ }^{5}$ Servicio Hidrográfico y Oceanográfico de la Armada de Chile, Errazuriz 232, Casilla 324, Valparaíso, Chile \\ ${ }^{6}$ Centro Universitario de la Trapananda, Portales 73, Coyhaique, Chile \\ ${ }^{7}$ Centro de Investigaciones en Ecosistemas Patagónicos, Bilbao 550, Coyhaique, Chile
}

\begin{abstract}
The inlets of southern Chile are characterized by a well-defined pycnocline which, acting in concert with the biological characteristics of larvae, is believed to influence planktonic larval distribution. Here, we assessed the effects of stratified flow over a sill on the spatial abundance and distribution of epineustonic competent larvae of Concholepas concholepas. We used measurements of velocity profiles using an Acoustic Doppler Current Profiler (ADCP), intensive plankton collections combined with simultaneous conductivity, temperature and depth (CTD) profiles, monitoring of the pycnocline depth, and temperature records from moored thermistors. Evidence of Bernoulli aspiration and an intratidal transient front was observed over the sill from CTD data and an echosounder trace. ADCP measurements showed intensified recirculation in the residual flow over the sill. This oceanographic feature coincided with high abundances of epineustonic competent larvae of C. concholepas over the sill area. We found evidence indicating that physical mechanisms related to sill processes can influence epineustonic competent larval distribution in a stratified system. We also propose a conceptual model that brings together larval behaviour and stratified flow patterns to explain the rise of epineustonic larvae to the surface and larval aggregation over a sill.
\end{abstract}

KEY WORDS: Bernoulli aspiration · Sill · Epineustonic larvae $\cdot$ Stratified system $\cdot$ Southern Chile Resale or republication not permitted without written consent of the publisher

\section{INTRODUCTION}

The transport of planktonic larvae may be affected by a combination of biological characteristics in terms of larval development and oceanographic features (Ewing 1950, Le Fèvre 1986, Scheltema 1986, Fairweather 1991, Levin \& Bridges 1995, Shanks 1995, Wing et al. 1995, Young 1995, Pineda 1999). Through their behaviour, larvae can control their horizontal distribution (Shanks 1995, Young 1995, Poulin et al. 2002a) and thereby influence their dis- persal and local abundance (Shanks 1995, Natunewicz \& Epifanio 2001). This may be an adaptive response to exploit predictable flow patterns (Shanks 1995), as observed in crustaceans in coastal waters and estuaries. In these areas, early stages remain at the surface as they are advected offshore, whereas late stages show an ontogenetic shift that keeps them in deeper waters with a landward flow (e.g. Carcinus maenas, Hemigrapsus sanguineus, Anomalocera ornata) (Queiroga et al. 2002, Park et al. 2004, Tester et al. 2004). 
Oceanographic features, such as fronts, could play an important role in larval distribution by acting as retention areas for invertebrate and fish larvae (Penven et al. 2000, Kasai et al. 2002, Acha et al. 2004). In fjord areas, the barotropic flow over a sill may modify the interfacial height and wave speed of the stratified layers in the 'control section' (usually the sill, Farmer \& Armi 1986). Depending on the transverse sectional area of exchange, the sill can obstruct the flow and lead to 2 phenomena known as blocking and choking (Farmer \& Denton 1985). These phenomena tend to produce a front upstream (relative to the barotropic flow direction) of the sill crest (Farmer \& Armi 1986). Furthermore, high flow speeds over a sill reduce the dynamic pressure to such extent that dense waters from below sill depth are uplifted onto the sill (Seim \& Gregg 1997). This aspiration of waters from below the pycnocline increases mixing and surface water density (Seim \& Gregg 1997, Valle-Levinson et al. 2006), which also contribute to the surface flow convergence.

The inlets of Chile ( 42 to $56^{\circ} \mathrm{S}$ ) are characterized by a stratified water column and several areas of steep bathymetric and morphologic changes (Pickard 1971). Tidal forcing (Valle-Levinson et al. 2001, 2002, Cáceres et al. 2003) or wind forcing (Valle-Levinson \& Blanco 2004) can substantially modify the observed 2-layer exchange, and these modifications in turn contribute to a redistribution of dissolved and suspended materials. Furthermore, the flows on either side of the constrictions may be associated with recirculation (Cáceres \& Valle-Levinson 2004), which influences plankton distributions.

Concholepas concholepas (Bruguiere, 1789) (Gastropoda, Muricidae) is a benthic species (Castilla \& Durán 1985, Moreno et al. 1986) distributed along the entire coast of Chile (Stuardo 1979). The life history of this species involves intracapsular development and a long planktonic larval stage that lasts between 6 and 12 mo in the fjords of southern Chile (Molinet et al. 2005). Planktonic development ends with an epineustonic competent veliger larva that settles in rocky intertidal and shallow subtidal habitats (Stotz et al. 1991, Moreno et al. 1993, Martínez \& Navarrete 2002, Manríquez et al. 2004). C. concholepas competent larvae have been found at the surface during the day, suggesting inverse diel vertical migration (Poulin et al. 2002b), and forming aggregations in slick bands (Moreno et al. 1993, DiSalvo \& Carriker 1994, Peña et al. 1994). They have also been found distributed homogeneously in recently upwelled cold water, suggesting that upwelling events could influence their near-shore spatial distribution (Poulin et al. 2002b) and settlement patterns (Moreno et al. 1998). C. concholepas competent larvae have been found during most of the year along the south central coast of Chile (Moreno et al.
1993, Peña et al. 1994, Poulin et al. 2002). In contrast, although early veliger larvae have been found in stratified channels in Southern Chile almost throughout the year (Molinet et al. 2005), competent larvae have only been found here between June and August.

The objective of this investigation was to assess the effects of stratified flow on the spatial abundance and distribution of Concholepas concholepas competent larvae. This objective was addressed in a channel with a characteristic northern sill. Three processes have been suggested that could produce particle concentration around the sill area: (1) phase lag of tidal flows, (2) aspiration of below-pycnocline waters, and (3) recirculation (Cáceres et al. 2006). We found evidence that these processes help C. concholepas epineustonic competent larvae rise to the surface in stratified systems and form aggregations at the surface, where they remain. Finally, we propose a model that combines larval behaviour and flow patterns to explain the rise of epineustonic larvae to the surface and their aggregation over a sill with stratified flow.

\section{MATERIALS AND METHODS}

Study area. The study was conducted in Refugio Channel $\left(43^{\circ} 58^{\prime} \mathrm{S}, 73^{\circ} 07^{\prime} \mathrm{W}\right)$, in the northeastern part of southern Chile's inlets (Fig. 1B). The water column is strongly influenced by freshwater runoff, causing salinity to range between 5 and 33 psu in the first $10 \mathrm{~m}$ of the water column (Molinet et al. 2005). Refugio Channel has a north-south orientation and measures $\sim 13 \mathrm{~km}$ long and 1 to $2 \mathrm{~km}$ wide (Fig. 1B). The most salient bathymetric characteristic feature of this channel is a sill located in the northern third of the channel, $40 \mathrm{~m}$ deep on its west side and $65 \mathrm{~m}$ on its east side. The sill is topped by Frondoso Islet, which splits the channel into 2 basins. To the south is a narrow basin with a steep coastal slope and a maximum depth of $200 \mathrm{~m}$ immediately west of Larga Island. To the north is a wider basin, with a milder bottom slope and a maximum depth of $90 \mathrm{~m}$.

Data collection. In order to understand the influence of the sill on local circulation and the effects of flow patterns on larval distribution, we obtained underway velocity profiles, records of temperature over the sill, intensive plankton samples upstream, over, and downstream from the sill combined with simultaneous records of density profiles, and echo sounder paper records of the pycnocline position.

Current velocity profiles were sampled with a Workhorse 307.2 KHz RD-Instruments acoustic Doppler current profiler (ADCP) along 3 transects: (1) western (along-channel), (2) northern (across-channel), and (3) eastern (along-channel) (Fig. 2A). We sampled these 


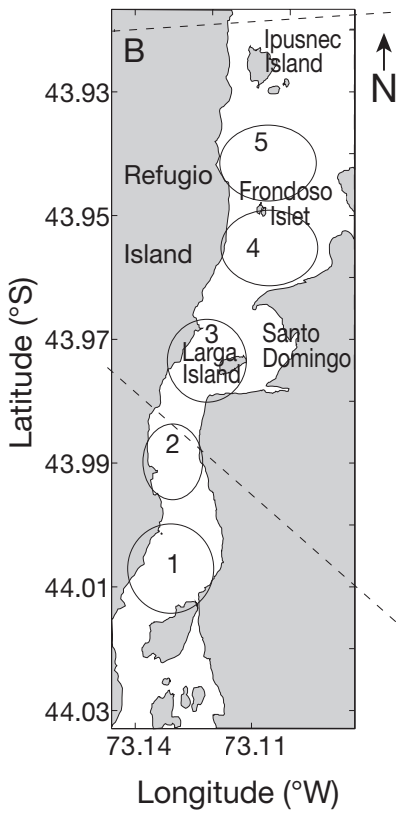

Longitude $\left({ }^{\circ} \mathrm{W}\right)$

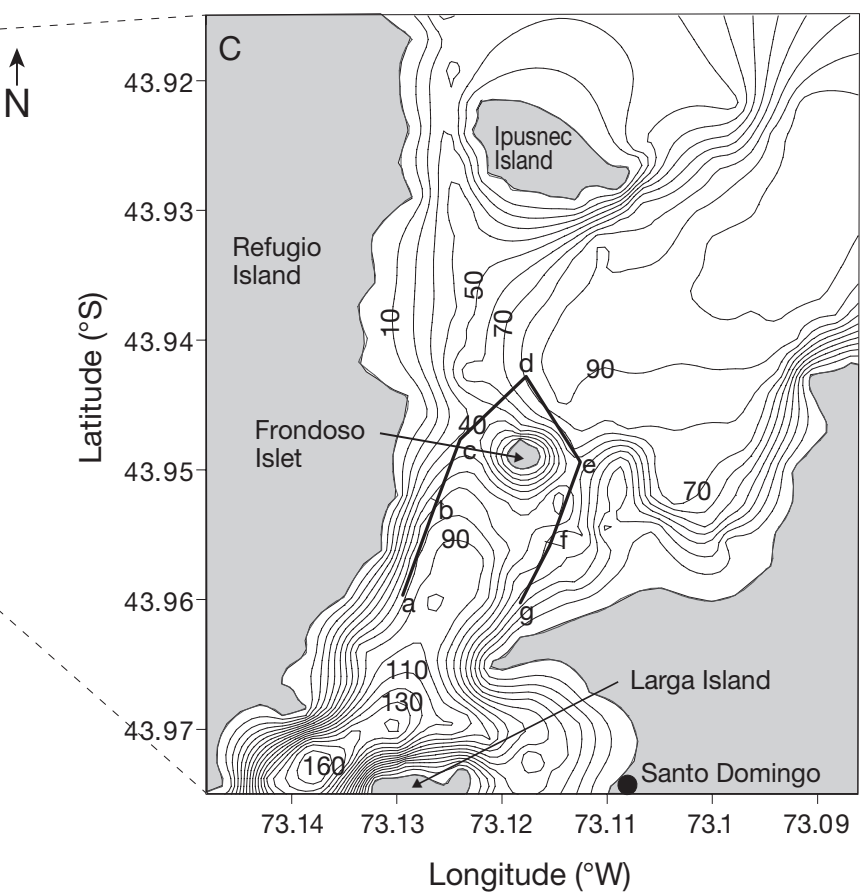

Fig. 1. (A) Study area in southern Chile (indicated by arrow). (B) Refugio Channel in the southeast of the Gulf of Corcovado. Stations located along the channel are numbered and circled (Modes 1 and 2). (C) Detailed study area over the sill (Mode 3) showing the bathymetry contoured every $10 \mathrm{~m}$, with a sill located around Frondoso Islet. Continuous lines represent cruise trajectory for Mode 3 CTD profiles in the western transect (Stns a-d) and the eastern transect (Stns $d-g$ ). (๑) Location of the meteorological station at Santo Domingo

Fig. 2. Study area, showing (A) trajectory of ADCP velocity profiles along the western, northern, and eastern transects (dashed lines) during June 2002; (B) residual flow along the western transect; and (C) residual flow along the eastern transect of Refugio Channel

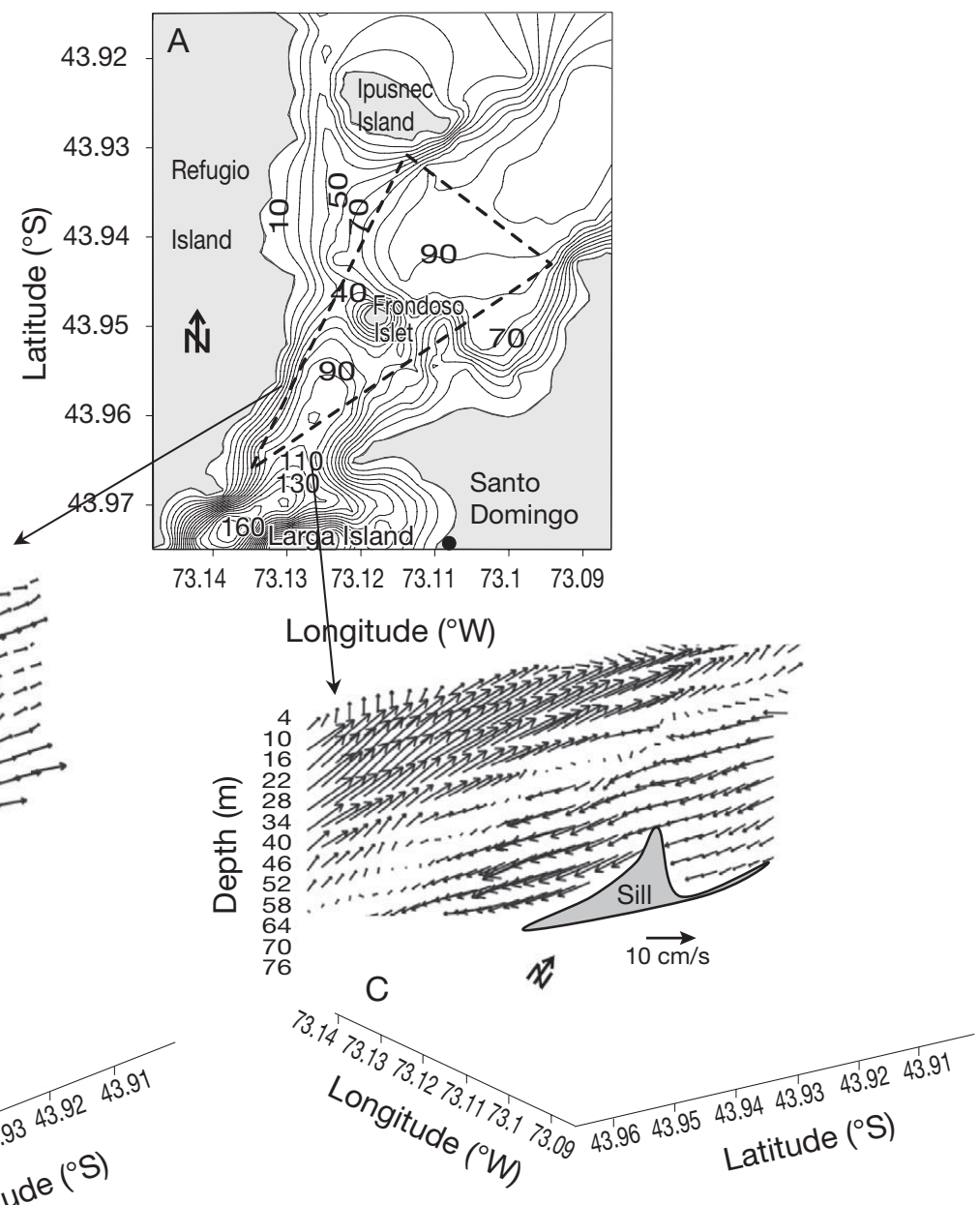


transects 14 times during a $25 \mathrm{~h}$ period. The ADCP was towed on a $1.2 \mathrm{~m}$ long catamaran along the starboard side of the RV 'Bellavista' at speeds between 2.0 and $2.5 \mathrm{~m} \mathrm{~s}^{-1}$. Velocity profiles with a vertical resolution of $2 \mathrm{~m}$ and ping rates of $\sim 1 \mathrm{~Hz}$ were averaged every $60 \mathrm{~s}$, yielding a spatial resolution of 120 to $150 \mathrm{~m}$. The ADCP compass was calibrated using Global Positioning System (GPS) navigation data (Trump \& Marmorino 1997).

Seawater temperature loggers (Stow Away Tidbit) recorded at $1 \mathrm{~h}$ intervals between January and December 2002 and between March and December 2003. These thermistors were moored over the sill area (100 m southwest of Frondoso Islet) at depths of 0.1, 10, and $40 \mathrm{~m}$ (Fig. 1B). Between March and December 2003, we also recorded temperature with moored thermistors at Stn 4 (100 m west from Larga Island) at depths of $0.1,10,50 \mathrm{~m}$, and $90 \mathrm{~m}$ (Fig. 1B). Meteorological data were recorded at $1 \mathrm{~h}$ intervals with a Davis Instruments meteorological station located at Santo Domingo (Fig. 1B) during the entire study period.

Concholepas concholepas competent veliger larvae (CV) were sampled in 3 modes from January 2003 to December 2003 along Refugio Channel. In all modes, samples were collected by towing a floating neustonic plankton net $(1 \mathrm{~m}$ wide $\times 0.3 \mathrm{~m}$ deep $\times 2 \mathrm{~m}$ long; $500 \mu \mathrm{m}$ mesh size) (Moreno et al. 1993) alongside a $7 \mathrm{~m}$ long fiberglass boat. The towed distance was recorded with a flow meter positioned in the mouth of each net during each tow.

Mode 1: Fortnightly samples were collected from January to December 2003 at both a southern and a northern station within Refugio Channel (Stns 1 and 4 in Fig. 1B).

Mode 2: When CV larvae of Concholepas concholepas were found in Mode 1, samples were taken twice per day from the 5 stations along the channel (Fig. 1B) to monitor abundance. One sample was collected in the morning (AM, between sunrise and zenith) and another in the afternoon (PM, between zenith and sunset).

Mode 3: Additional samples were taken over specific portions of the channel where more than 20 Concholepas concholepas larvae $\mathrm{km}^{-1}$ were observed during Mode 2. This happened on 15 July 2003, but unfavourable meteorological conditions prevented the collection of samples during the following $4 \mathrm{~d}$. Another spot of high larval abundance was observed in the afternoon of 29 July 2003, between Stns 4 and 5 .

On 30 July 2003, a simultaneous Mode 3 plankton collection and 7 CTD casts (a-g in Fig. 1C) were done with a Seabird SBE-19 instrument and a Garmin 183 GPS for station positioning. The route covered 6 plankton-sampling sectors (Fig. 1C): the western transect $(\mathrm{a}-\mathrm{d})$ and the eastern transect $(\mathrm{d}-\mathrm{g})$ were each sampled 4 times (every $1.5 \mathrm{~h}$ ). Furthermore, soundings with a 50 kHz Furuno FE 6300 echo sounder were conducted during plankton collection and recorded on paper to represent the depth of the pycnocline in the water column along each transect.

Data analysis. Current velocity data were depurated following the approach of Valle-Levinson \& Atkinson (1999). After the heading correction was applied, the data were rotated counter clockwise to an along( $v$ flow) and across- ( $u$ flow) channel coordinate system. These angles were oriented in the direction of greatest variability of the tidal currents and of weakest across-channel tidal flows. Semidiurnal $\left(M_{2}\right)$ and diurnal $\left(K_{1}\right)$ constituents were separated from the subtidal signal of the observed flow components using sinusoidal least squares regression analysis (Lwiza et al. 1991). This was done to determine tidal and subtidal (or residual) contributions to the observed flow. Temperatures recorded with moored temperature loggers were analysed through spectral analysis (FFT) (Emery \& Thomson 1997).

CV larval abundances did not have a normal distribution and were therefore analyzed using non-parametric tests. The Mann-Whitney $U$-test was used to compare larval abundance between the western transect and the eastern transect (Zar 1999). The KruskalWallis $(H)$ test with an a posteriori Dunn test was applied to compare larval abundance observed along the Refugio Channel and between the sample dates (Zar 1999). The paper records of echo soundings were scanned to produce digital images that were then cropped to the area of the sill using Surfer v7.0. CTD data obtained during Mode 3 were processed using the manufacturer's software. The processed data were used to produce density profiles along both eastern and western transects.

\section{RESULTS}

The temporal variability of the flow in this region is clearly dominated by the semidiurnal tides. The residual tidal flow obtained from ADCP data at the western transect showed a 2-layer exchange over the southern portion of the transect and over the top of the sill (Fig. 2B). The exchange flow featured a near-surface northward flow of $20 \mathrm{~cm} \mathrm{~s}^{-1}$ and a near-bottom southward flow of $10 \mathrm{~cm} \mathrm{~s}^{-1}$. In contrast, only a northward residual flow was observed in the whole water column over the northern portion of the western transect $\left(<10 \mathrm{~cm} \mathrm{~s}^{-1}\right)$ (Fig. 2B). The residual flows also suggested a tendency to form an anticyclonic circulation at the surface over the sill region along the western transect, implying residual flow recirculation in this area (Fig. 2B).

Along the eastern transect, the residual flow showed a 2-layer structure with a northward surface flow of 
$20 \mathrm{~cm} \mathrm{~s}^{-1}$ and a southward near-bottom flow of $20 \mathrm{~cm}$ $\mathrm{s}^{-1}$ (Fig. 2C). The anticyclonic residual flow observed along the western transect was not observed on the eastern side of Frondoso Islet.

Unfortunately, the temperature loggers moored at Stn 4 (Frondoso Islet) were lost during 2003; therefore, our analysis relies on data recorded during 2002 in this area and during 2003 at Stn 3 (Larga Island). The spectra of sea temperature data from thermistors moored to the west of Frondoso Islet during 2002 revealed peaks around the diurnal (at $0.1 \mathrm{~m}$ depth) and semidiurnal (at $0.1,10$ and $40 \mathrm{~m}$ depth) components of the tides (Fig. 3A). The spectra of the thermistors moored at Stn 3 showed peaks only at the surface, showing the same frequency that was observed at Frondoso Islet (Fig. 3B). Also, the lowest sea surface temperature anomaly (SSTA) was observed in October 2003, whereas the highest SSTA was observed in July and August 2003.

During Mode 1, 48 samples were collected along Refugio Channel, finding CV larvae (in surface samples) only in July (mean = 45 larvae $\mathrm{km}^{-1}, \mathrm{SD}=36$ ) and August (mean $=7$ larvae $\mathrm{km}^{-1}, \mathrm{SD}=9$ ). During Mode 2, 60 samples were collected from 10 July to 1 August 2003, and CV larvae were always found in association with surface slicks. However, only the data obtained on 10,11, 15, 27, and 29 July and on 1 August 2003 were used in the analysis, because not all of the channel sectors were sampled on the other dates.

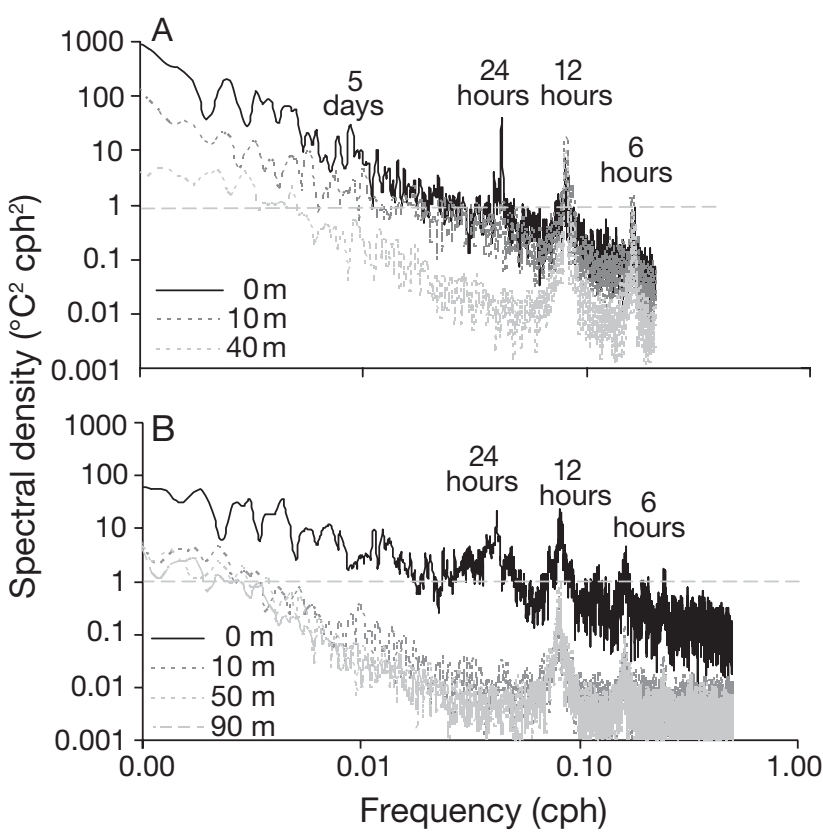

Fig. 3. Spectral (Fourier) analysis of sea temperature data obtained from thermistors moored (A) over the sill at the surface, $8 \mathrm{~m}$, and $40 \mathrm{~m}$ depth and (B) west of Larga Island at the surface, $8 \mathrm{~m}, 40 \mathrm{~m}$, and $90 \mathrm{~m}$ depth, in Refugio Channel. Gray dashed lines show the significance level (95\%)
The median abundance of CV larvae found during Mode 2 was 2.7 larvae $\mathrm{km}^{-1}$. The CV larval abundances found in AM samples (median = 7 larvae $\mathrm{km}^{-1}$ ) were significantly higher than those of PM samples $\left(\right.$ median $=0$ larva $\left.\mathrm{km}^{-1}\right)\left(U_{0.05,20,32, \mathrm{df}=1}=203, \mathrm{p}=0.027\right)$. Likewise, CV larval abundances were significantly different depending on the day of sampling $\left(H_{0.05,52, \mathrm{df}=5}=\right.$ $22.4, \mathrm{p}=0.000$ ). The highest larval abundance (median = 13.7 larvae $\mathrm{km}^{-1}$ ) was observed on 15 July 2003 and the lowest (median $=0$ larvae $\mathrm{km}^{-1}$ ) on 27 July 2003 (Fig. 4). CV larval abundances along the channel were not significantly different $\left(H_{0.05,50, \mathrm{df}=4}=1.2, \mathrm{p}=0.88\right)$, although on 29 July 2003, larvae were observed aggregated around Stn 4 (95 larvae $\mathrm{km}^{-1}$ ) (Fig. 4E). Wind velocities were less than $2 \mathrm{~m} \mathrm{~s}^{-1}$ during the first $4 \mathrm{~d}$ of sampling $(10,11,15$, and 27 July 2003) and coincided with a more homogeneous distribution of larvae along the channel; winds up to $10 \mathrm{~m} \mathrm{~s}^{-1}$ were recorded on 29 July 2003 when larvae were observed aggregated at Stn 4 (Fig. 5).

During Mode 3, a total of 24 samples were taken along the western and eastern transects (09:00 to 17:30 h, 30 July 2003). The highest abundance of CV larvae was observed along the western transect (median $=4.7$ larvae $\mathrm{km}^{-1}$ ) during the flood tide and the lowest along the eastern transect (median $=0$ larvae $\mathrm{km}^{-1}$ ) during the ebb tide.

Along the western transect, the highest abundance of CV larvae was observed during the first pass along sector b-c (Fig. 6A), when a convergent surface flow was evident from surface seawater density (Fig. 6B) and a sharp frontal pycnocline (Fig. 6C). Furthermore, density profiles in this transect suggest aspiration of dense water from below the sill (Seim \& Gregg 1997).

CV larval abundances gradually diminished between the second and fourth western transects (Fig. 6D,G,J), surface seawater density variations decreased (Fig. 6E,H,K), and the pycnocline became milder (Fig. 6F,I,L). In the fourth pass along the western transect, the pycnocline was widespread through most of the water column in the region over the sill (Fig. 6L).

Along the eastern transect, CV larval abundances were lower than along the western transect; the highest abundance values were found during the first pass over the transect, as observed along the western transect (Fig. 7A). Density profiles revealed a weaker superficial convergence and the frontal pycnocline in this transect was not as clear as it was in the first western transect. Larval abundances in eastern transects 2 , 3 , and 4 were very low (Fig. 7D,G,J), whereas surface water density was more vertically stratified than it was in the western transects (Fig. 7E, $\mathrm{H}, \mathrm{K}$ ). The pycnocline became weaker in transect 2 and abrupt changes were 


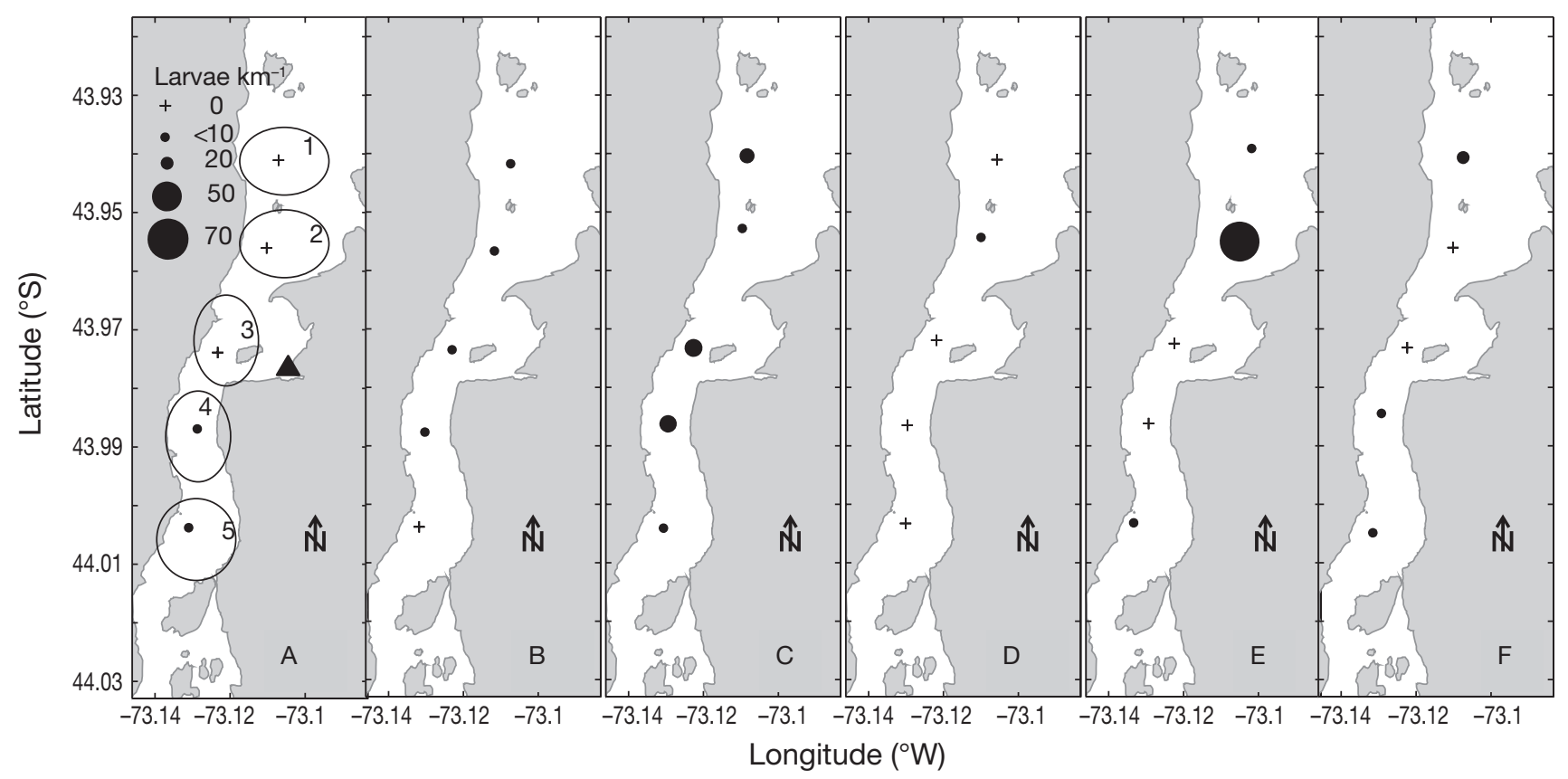

Fig. 4. Larval abundance along the channel at each sampled station. (A) 10 July, (B) 11 July, (C) 15 July, (D) 27 July, (E) 29 July, and $(\mathrm{F}) 1$ August. ( $\mathbf{\Delta}$ ) Location of meteorological station

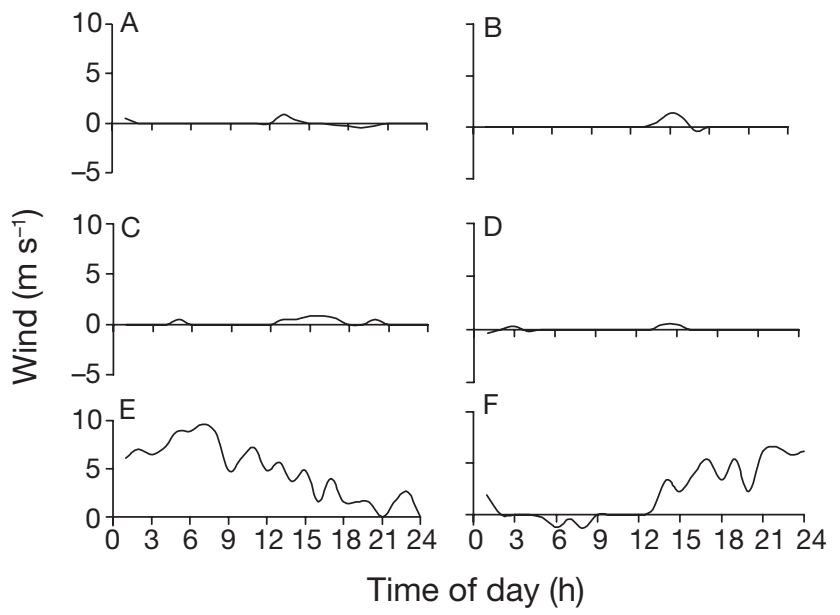

Fig. 5. North-south component of winds in Refugio Channel during the study. (A) 10 July, (B) 11 July, (C) 15 July, (D) 27 July, (E) 29 July, and (F) 1 August

observed in the pycnocline in transects 3 and 4 (Fig. 7F,I,L), as observed in the fourth western transect.

The CV larval abundances found in the western and eastern transects were significantly different $\left(U_{0.05,12,12, \mathrm{df}=1}=36.5, \mathrm{p}=0.04\right)$, with higher abundances being observed in the western transects than in the eastern transects. However, larval abundances did not show significant differences between plankton sampling sectors in the western $\left(H_{2,12}=2.4, \mathrm{p}=0.3\right)$ or eastern transects $\left(H_{0,05,12, \mathrm{df}=2}=1.3, \mathrm{p}=0.5\right)$.

\section{DISCUSSION}

Concholepas concholepas competent larvae were only confirmed during July and August in Refugio Channel despite the fact that early veliger larvae were observed throughout almost the entire year in this area (Molinet 2005, Molinet et al. 2005). Competent larvae were abundant around the region over the sill, where Bernoulli aspiration was implied along the western transect from density profiles and the position of the pycnocline, which coincided with that observed by Cáceres et al. (2006). Moreover, ADCP measurements showed intensified recirculation in the residual flow in the area over the sill.

Salinity is the principal variable influencing the pycnocline in Chilean inlets (Pickard 1971). In these areas, salinity has been reported to affect Concholepas concholepas larval distribution by acting as a physical or chemical barrier that blocks the arrival of competent larvae at the surface (Molinet 2005, C. Molinet et al. unpubl.). Contoured density fields obtained during this study (Fig. 6) suggest aspiration of dense water from below the pycnocline, as proposed by Cáceres et al. (2006). A transient superficial convergent flow was found using density profiles and the recorded pycnocline position. This coincided with the highest observed abundance of $C$. concholepas CV larvae in the area over the sill.

Based on this evidence, we propose that vertical migration could bring the competent larvae of Concho- 
Western Transect 1
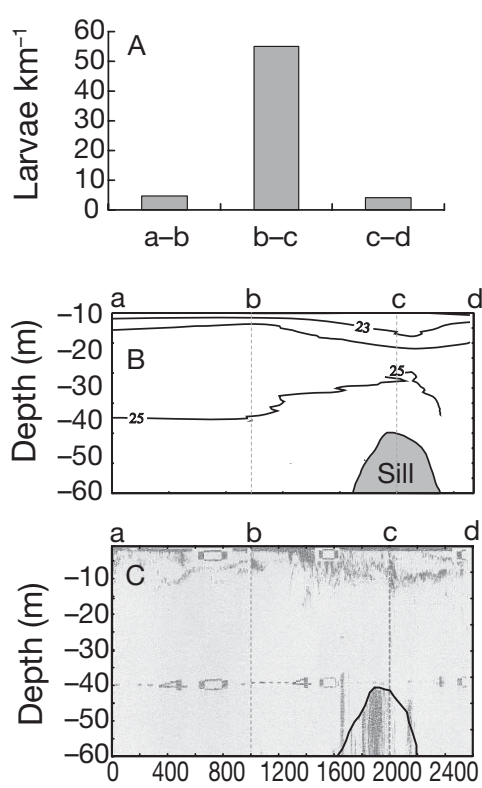

Western Transect 2
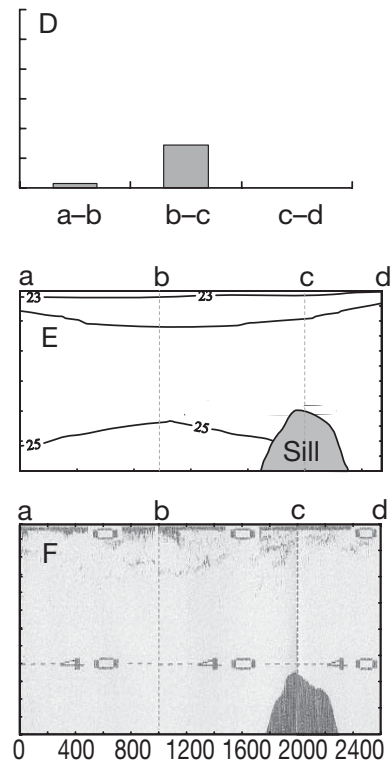

Western Transect 3
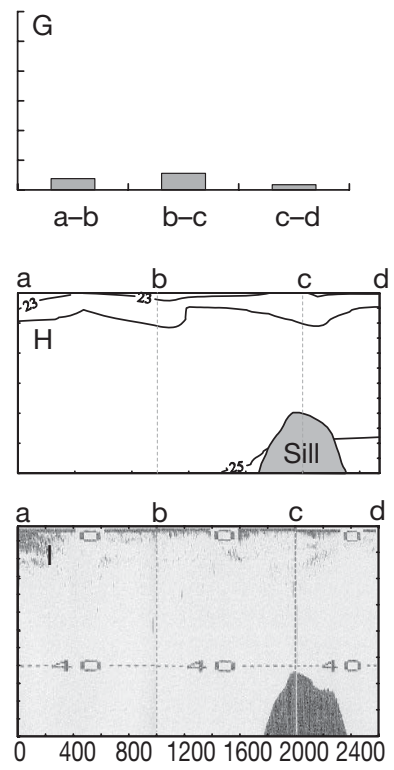

Distance $(\mathrm{m})$
Western Transect 4
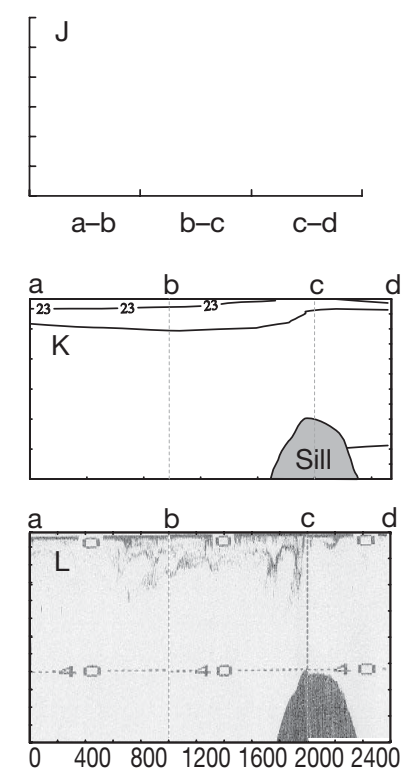

Fig. 6. Concholepas concholepas. Competent larval abundance along the western transects (sector a-b, b-c, and c-d) in all transects (A, D, G, and J). Density fields obtained with CTD vertical profiles at Stns a, b, c, and d (vertical dotted gray lines) in all transects $(B, E, H$, and $K)$. Echo soundings recorded on paper to represent the depth of the pycnocline in the water column along each western transect (C, F, I, and L)

Eastern transect 1
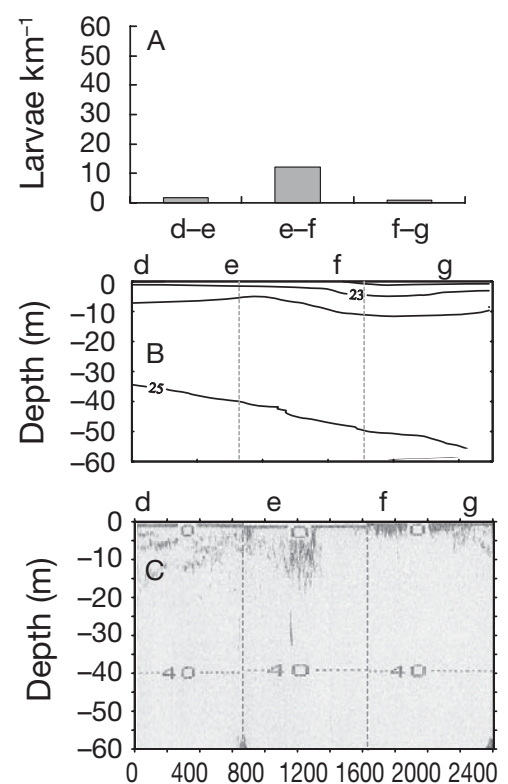

Eastern transect 2
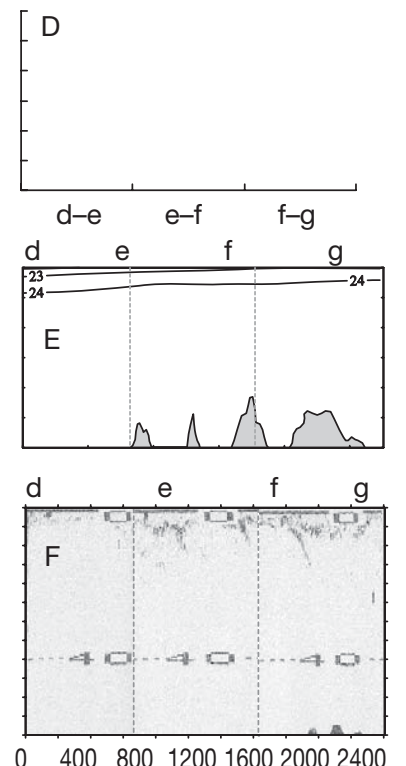

Eastern transect 3
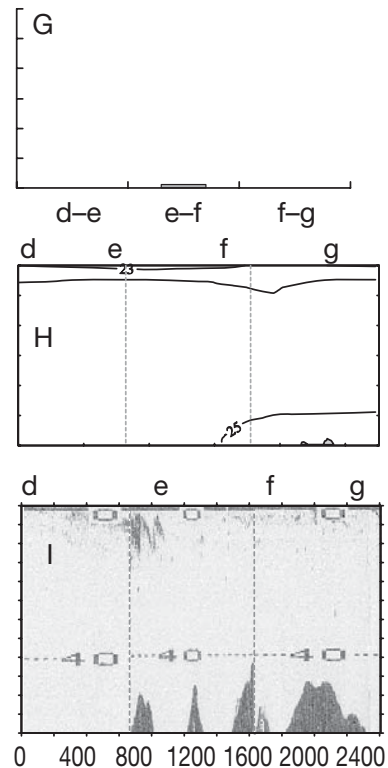

04008001200160020002400

\section{Eastern transect 4}
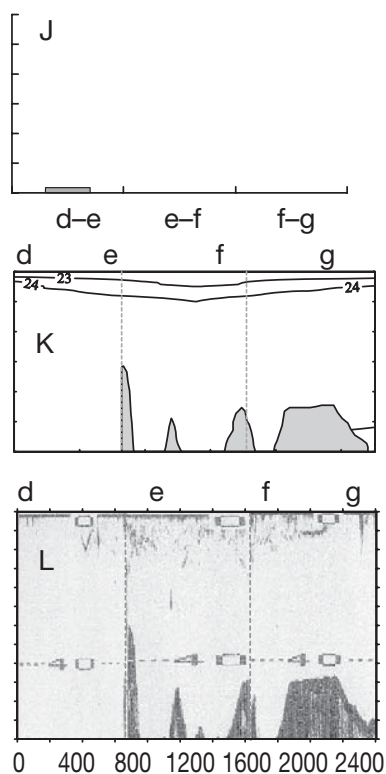

Distance $(\mathrm{m})$

Fig. 7. Concholepas concholepas. Competent larval abundance along the eastern transects (sector $\mathrm{d}-\mathrm{e}$, e-f, and $\mathrm{f}-\mathrm{g}$ ) in all transects (A, D, G, and J). Density fields obtained with CTD vertical profiles at stations d, e, f, and g (vertical dotted gray lines) in all transects $(B, E, H$, and $K)$. Echo soundings recorded on paper to represent the depth of the pycnocline in the water column along each eastern transect (C, F, I, and L) 
lepas concholepas to the surface where they remain during the day (Poulin et al. 2002a), although in stratified systems the larvae are constrained from arriving at the surface by low salinity in the superficial layer (Molinet et al. 2005) (Fig. 8A). The aspiration of belowpycnocline waters to the surface during the flood tide could affect larval distribution in 2 ways. First, the barrier from the pycnocline is eliminated, allowing upward-swimming larvae to arrive at the surface and helping deeper larvae reach the surface (Fig. 8B). Second, aspiration causes a sharp tidal intrusion front at the surface (as observed in Fig. 6B,C), concentrating competent larvae at the surface convergence (Fig. 8C), possibly amplified by residual recirculation over the western side of the sill. Finally, larvae could be dispersed by vertical or horizontal mixing or advected to the coast where they settle (Fig. 8D). These physical features were consistent with semidiurnal peaks of spectral density from the water column temperature records over the sill and SST records from Larga Island, suggesting a semidiurnal frontogenesis pattern produced by tidal forcing in this channel. This also coincided with backscatter records observed in ADCP measurements from 2002 showing a frontal pycnocline in the same tidal period (Molinet et al. 2004).

The results suggest that the short period of time during which competent larvae are found in Refugio Channel, despite the nearly year-round presence of early veliger stages, could be explained by the frequent inability of the larvae to reach the surface. The persistent of water column stratification diminishes the probability of finding them. However, if a semidiurnal frontogenesis pattern exists over the sill area and early veliger stages are observed almost throughout the year. Why are abundant competent larvae found only during July in this channel? The higher larval abundance observed along the channel on 15 and 29 July 2003 coincided with the lunar cycle and a strong positive SSTA recorded at Larga Island. Likewise, the strong positive SSTA coincided with the lowest sea surface temperature and air temperature of the year, suggesting a seasonal stratification pattern of the water column. We hypothesize that such stratification could affect the energy of the sill processes and internal waves along the Refugio Channel (Ewing 1950), as well as plankton abundance and distribution in this area. This hypothesis requires further study.

Although larvae could reach their competent stage before July in this area, they cannot arrive at the surface, which agrees with observations of occasional CV larvae in this channel during intensive sampling carried out between March and May (Molinet 2005). The limited data set obtained in this study did not allow us to reject alternative hypotheses that explain the arrival of competent larvae to Refugio Channel. Alternative

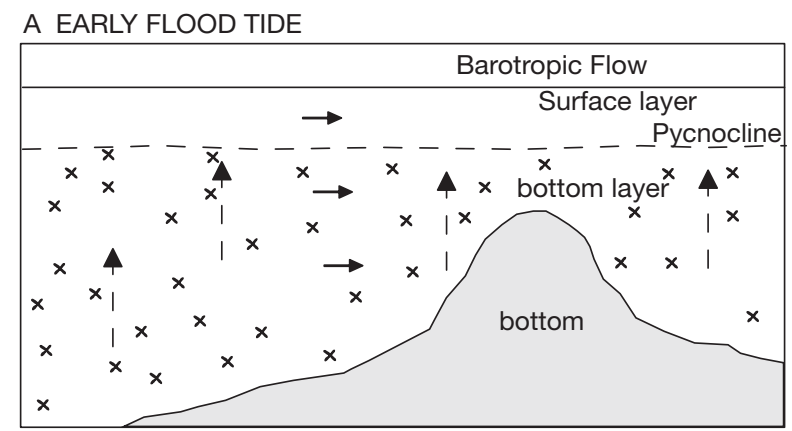

B LATE FLOOD TIDE

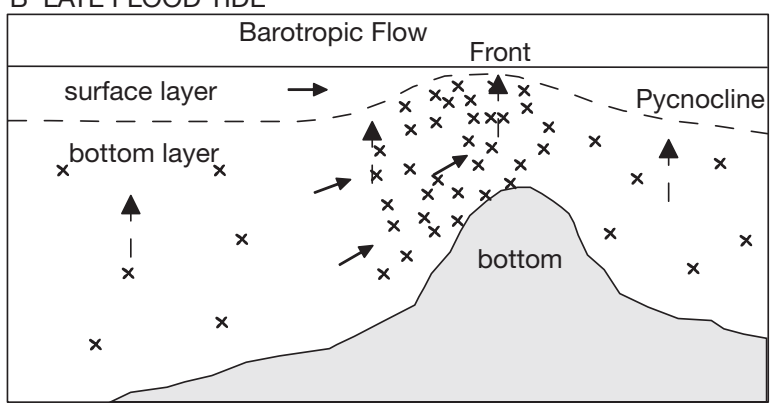

C LATER FLOOD TIDE

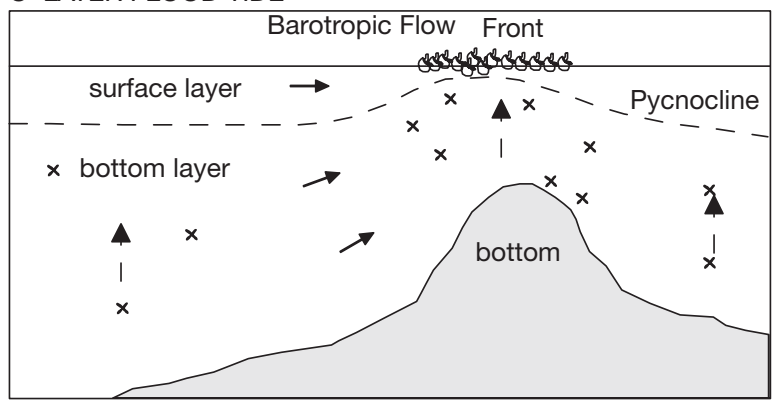

D FLOOD TIDE TO EARLY EBB

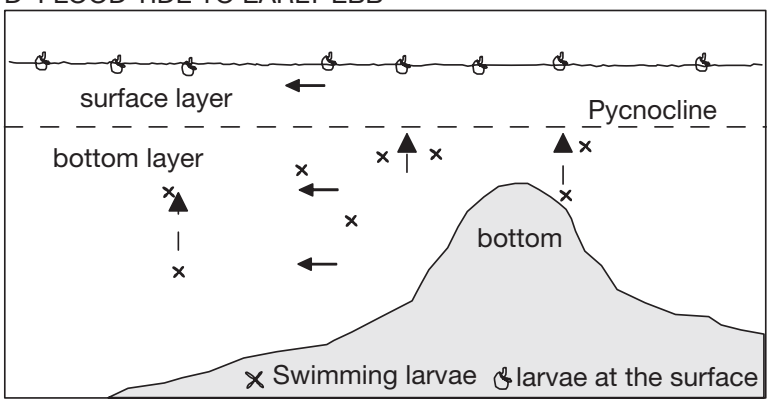

Fig. 8. Concholepas concholepas. Simplified model explaining aggregation of epineustonic competent larvae in the area over the Refugio Channel sill. (A) CV larvae are constrained from arriving at the surface by the effect of the pycnocline. (B) High flow speeds over a sill (produced by the effect of barotropical flow during flood tide) reduce the dynamic pressure to such an extent that dense waters from below the sill are uplifted onto the sill. The aspiration of below-pycnocline waters to the surface breaks the barrier of the pycnocline, allowing upward-swimming larvae to reach the surface. (C) Aspiration causes a sharp tidal intrusion front at the surface, concentrating competent larvae at the superficial convergence. (D) Finally, larvae could be dispersed by vertical or horizontal mixing or advected to the coast, where they settle 
explanations could be related to pulses of competent larval arriving from oceanic areas by wind-driven transport or subinertial waves (baroclinic or barotropic). These hypotheses shall be the focus of future studies in Refugio Channel.

The mechanism that breaks the pycnocline in Refugio Channel must be a key event for the arrival of Concholepas concholepas competent larvae at the surface and their settlement in a stratified system. This could also be fundamental for the observed distributional patterns of adult stocks of this species in Chilean inlets with stratified flow, which also requires further study.

The dense larval patch observed to the southeast of Frondoso Islet on July 29, coincided with southward winds up to $10 \mathrm{~m} \mathrm{~s}^{-1}$, suggesting that larval aggregation at the surface could be directly influenced by wind drift. This is consistent with Lagrangian current studies of this channel showing that moderate southward winds influence southeastward surface circulation (Molinet 2005).

We found evidence of 2 physical mechanisms that can influence epineustonic competent larval distribution in a stratified system. First, there was evidence of Bernoulli aspiration at flood tide, raising the high salinity below-pycnocline water to the surface and allowing the larvae to reach the surface and concentrate in the frontal convergence. Second, the surface flow was influenced by coastal morphology that promoted recirculation and larval aggregation on the west side of the sill.

Acknowledgements. We thank J. L. Barra, J. A. Barra, and S. Inarejo for the enthusiastic field assistance in Santo Domingo. Comments by 3 anonymous reviewers helped improve this paper. The Scientific and Technological Development Fund (FONDEF) of Chile provided financial support for this research. This work was performed while the first author was a student in the Science Doctorate Program and received support from the National Commission for Scientific and Technological Research (CONICYT) of Chile. A.V.-L. acknowledges support from the US National Science Foundation project 9983685 .

\section{LITERATURE CITED}

Acha EM, Mianzan HW, Guerrero RA, Favero M, Bava J (2004) Marine fronts at the continental shelves of austral South America physical and ecological processes. J Mar Syst 44:83-105

Cáceres M, Valle-Levinson A (2004) Transverse variability of flow on both sides of a sill/contraction combination in a fjord-like inlet of southern Chile. Estuar Coast Shelf Sci 60:325-338

Cáceres M, Valle-Levinson A, Fierro J, Bello M, Castillo M (2003) Variabilidad longitudinal del flujo en canales con influencia batimétrica y topográfica. In: CONA (ed) Resultados Crucero Cimar 8 Fiordos, Informes Preliminares. Comité Oceanográfico Nacional, Valparaiso, Chile, p 17-24
Cáceres M, Valle-Levinson A, Molinet C, Castillo M, Bello M (2006) Lateral variability of flow over a sill in a channel of southern Chile. Ocean Dyn (in press)

Castilla JC, Durán LR (1985) Human exclusion from the rocky intertidal zone of central Chile: the effects on Concholepas concholepas (Gastropoda). Oikos 45:391-399

DiSalvo LH, Carriker MR (1994) Planktonic, metamorphic, and early benthic behavior of the Chilean loco Concholepas concholepas (Muricidae, Gastropoda, Mollusca). J Shellfish Res 13:57-66

Emery WJ, Thomson RE (1997) Data analysis methods in physical oceanography, 1st edn. Elsevier Science, Amsterdam

Ewing GC (1950) Relation between band slicks at the surface internal waves in the sea. Science 111:91-94

Fairweather PG (1991) Implications of 'supply-side ecology' for environmental assessment and management. Trends Ecol Evol 6:60-63

Farmer DA, Armi L (1986) Maximal two-layer exchange over a sill and through the combination of a sill and contraction with barotropic flow. J Fluid Mech 164:53-76

Farmer DA, Denton RA (1985) Hydraulic control of flow over the sill in observatory inlet. J Geophys Res 90:9051-9068

Kasai A, Kimura S, Nakata H, Okazaki Y (2002) Entrainment of coastal water into a frontal eddy of the Kuroshio and its biological significance. J Mar Syst 37:185-198

Le Fèvre $J$ (1986) Aspects of the biology of frontal systems. Adv Mar Biol 23:163-299

Levin LA, Bridges TS (1995) Pattern and diversity in reproduction and development. In: McEdward L (ed) Ecology of marine invertebrate larvae. CRC Press, Boca Raton, FL, p 1-48

Lwiza KMM, Bowers DG, Simpson JH (1991) Residual and tidal flow at a tidal mixing front in the North Sea. Cont Shelf Res 11:1379-1395

Manríquez PH, Navarrete SA, Rosson A, Castilla JC (2004) Settlement of the gastropod Concholepas concholepas on shells of conspecific adults. J Mar Biol Assoc UK 84: 651-658

Martínez P, Navarrete SA (2002) Temporal and spatial variation in settlement of the gastropod Concholepas concholepas in the natural and artificial substrata. J Mar Biol Assoc UK 82:257-264

Molinet C (2005) Spatial and temporal distribution of Concholepas concholepas (Gastrópoda, Muricidae), veliger larvae in the inland seas of northwest Patagonian. PhD dissertation, Universidad Austral de Chile, Valdivia

Molinet C, Moreno C, Bello M, Cáceres M, Castillo M, ValleLevinson A (2004) Coastal fronts and their effects on larval accumulation of Concholepas concholepas in southern Chile. XII International Conference on Physics of Estuaries and Coastal Seas: Hydrodynamics and morphodynamics in estuaries and coastal seas. Instituto de Ingenieria Universidad Autonoma de Mexico, Merida

Molinet C, Arevalo A, Gonzalez MT, Moreno CA, Arata J, Niklitschek E (2005) Patterns of larval distribution and settlement of Concholepas concholepas (Bruguiere, 1789) (Gastropoda, Muricidae) in fjords and channels of southern Chile. Rev Chil Hist Nat 78:409-423

Moreno CA, Lunecke KM, Lépez MI (1986) The response of an intertidal Concholepas concholepas (Gastropoda) population to protection from man in southern Chile and the effects on benthic sessile assemblages. Oikos 46:359-364

Moreno CA, Asencio G, Ibañez S (1993) Patrones de asentamiento de Concholepas concholepas (Brugiere) (Mollusca: Muricidae) en la zona intermareal rocosa de Valdivia, Chile. Rev Chil Hist Nat 66:93-101 
Moreno CA, Asencio G, Duarte W, Marin V (1998) Settlement of the muricid Concholepas concholepas and its relationship with El Niño and coastal upwellings in southern Chile. Mar Ecol Prog Ser 167:171-175

Natunewicz CC, Epifanio CE (2001) Spatial and temporal scapes of patches of crab larvae in coastal waters. Mar Ecol Prog Ser 212:217-222

Park S, Epifanio CE, Grey EK (2004) Behavior of larval Hemigrapsus sanguineus (de Haan) in response to gravity and pressure. J Exp Mar Biol Ecol 307:197-206

Peña G, Huepe P, Lepez I, Aracena O, Olivares O, Santos C (1994) Registro de larvas de Concholepas concholepas en el plancton costero de Bahia San Vicente y Coliumo, VII Region. Bol Soc Biol Concepcion 65:81-87

Penven P, Roy C, Colin de Verdiere A, Largier JL (2000) Simulation of a coastal jet retention process using a barotropic model. Oceanol Acta 23:615-634

Pickard GL (1971) Some physical oceanographic features of inlets of Chile. J Fish Res Board Can 28:1077-1106

Pineda J (1999) Circulation and larval distribution in internal tidal bore warn fronts. Limnol Oceanogr 44:1400-1414

Poulin E, Palma AT, Leiva G, Hernández E, Martínez P, Navarrete SA, Castilla JA (2002a) Temporal and spatial variation in the distribution of epineustonic competent larvae of Concholepas concholepas along the central coastal of Chile. Mar Ecol Prog Ser 229:95-104

Poulin E, Palma AT, Leiva G, Narvaez D, Pacheco R, Navarrete SA, Castilla JA (2002b) Avoiding offshore transport of competent larvae during upwelling events: the case of the gastropod Concholepas concholepas in central Chile. Limnol Oceanogr 47:1248-1255

Queiroga H, Moksnes P, Meireles S (2002) Vertical migration behaviour in the larvae of the shore crab Carcinus maenas from a microtidal system (Gullmarsfjord, Sweden). Mar Ecol Prog Ser 237:195-207

Scheltema RS (1986) On dispersal and planktonic larvae of benthic invertebrates: an eclectic overview and summary of problems. Bull Mar Sci 39:290-322

Seim HE, Gregg MC (1997) The importance of aspiration and channel curvature in producing strong vertical mixing over a sill. J Geophys Res 102:3451-3472

Shanks AL (1995) Mechanisms of cross-shelf dispersal of

Editorial responsibility: Howard Browman (Associate Editor-in-Chief), Storebø, Norway larval invertebrates and fish. In: McEdward L (ed) Ecology of marine invertebrate larvae. CRC Press, Boca Raton, FL, p 323-368

Stotz WB, Lancellotti DA, Martinez DJ, De Amesti P, Perez E (1991) Variación temporal y espacial del registro de juveniles recien asentados de Concholepas concholepas (Bruguiere, 1789), en el intermareal rocoso de la IV Región, Chile. Rev Biol Mar 26:351-361

Stuardo J (1979) Sobre la clasificación, distribución y variación de Concholepas concholepas (Bruguiere 1789): un estudio de taxonomía Beta. Biol Pesq 12:5-38

Tester PA, Cohen JH, Cervetto G (2004) Reverse vertical migration and hydrographic distribution of Anomalocera ornata (Copepoda: Pontellidae) in the US south Atlantic bight. Mar Ecol Prog Ser 268:195-203

Trump CL, Marmorino GO (1997) Calibrating a gyrocompass using ADCP and DGPS data. J Atmos Ocean Tech 14: 211-214

Valle-Levinson A, Atkinson LP (1999) Spatial gradients in the flow over an estuarine channel. Estuaries 22:179-193

Valle-Levinson A, Blanco J (2004) Observations of wind influence on exchange flows in a strait of the Chilean inland sea. J Mar Res 62:721-741

Valle-Levinson A, Jara F, Molinet C, Soto D (2001) Observations of intratidal variability of flows over a sill/contraction combination in a Chilean fjord. J Geophys Res 106: 7051-7064

Valle-Levinson A, Cáceres M, Sepulveda HH, Holderied K (2002) Patrones de flujo en los canales asociados a la boca del seno Aysén. Cienc Tecnol Mar 25:5-16

Valle-Levinson A, Blanco J, Frangópulos M (2006) Hydrography and frontogenesis in a glacial fjord off the Strait of Magellan. Ocean Dyn (in press)

Wing SR, Largier JL, Botsford LW, Quinn JF (1995) Settlement and transport of benthic invertebrates in an intermittent upwelling region. Limnol Oceanogr 40:316-329

Young CM (1995) Behavior and locomotion during the dispersal phase of larval life. In: McEdward L (ed) Ecology of Marine Invertebrate Larvae. CRC Press, Boca Raton, FL, p 249-278

Zar JH (1999) Biostatistical analysis, 4th edn. Prentice-Hall, Upper Saddle River, NJ

Submitted: January 13, 2006; Accepted: March 25, 2006

Proofs received from author(s): September 20, 2006 